\title{
Cyst of accessory lacrimal gland
}

\author{
J. A. DURÁN ${ }^{1}$ AND J. CUEVAS ${ }^{2}$
}

From the ${ }^{1}$ Cátedra de Oftalmología and the ${ }^{2}$ Cátedra de Histologia, Universidad de Santiago de Compostela, Spain

SUMMARY We present a case of an epithelial cyst of the conjunctiva caused by the dilatation of an accessory lacrimal gland. The case is peculiar in regard to the size of the cyst and the absence of traumatic or inflammatory factors to explain the retention of fluid.

Only a few cases of cysts of the accessory lacrimal gland have been described.' In most of them the aetiology is clear, but in some sporadic cases it is unknown. ${ }^{2}$

\section{Case report}

A 29-year-old female patient had for 2 years previous to the consultation noticed that her right eye had been more closed than the left, and that a mass had appeared at the base of the superior conjunctival sac. This mass had increased gradually over the 2 years. She had experienced sporadic diplopia. No pain or other ocular symptoms were noted.

On examination slight ptosis of the right eye was observed. It was caused mechanically by a smooth, globular mass which could be depressed and $\mathbf{u}$ :ich caused no inflammatory reaction (Figs. 1,2). When the patient looked ahead this mass was hidden by the upper lid, but when she made vertical eye movements it was evident at the lid margin. The cyst originated in the superior fornix. The patient's visual acuity was

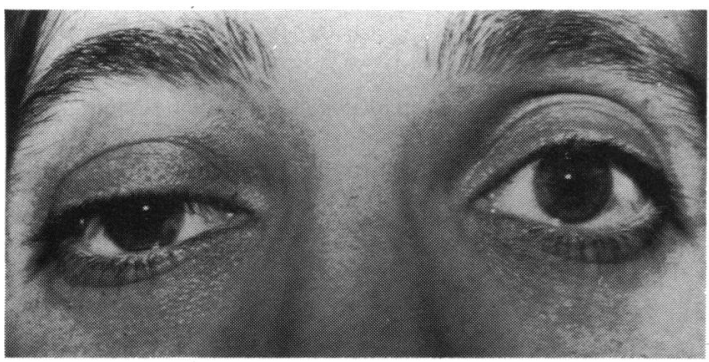

Fig. 1

Correspondence to Dr J. A. Durán de la Colina, Poza de Bar 33, Santiago de Compostela, Spain.
$20 / 20$ in the right eye and 20/20 in the left eye. As regards ocular motility, there was difficulty in superior adduction of the right eye, because there was vertical pseudostrabismus in the primary position caused by inferior displacement by the mass.

On excision the mass was seen to contain serumlike liquid. Ptosis disappeared during the follow-up

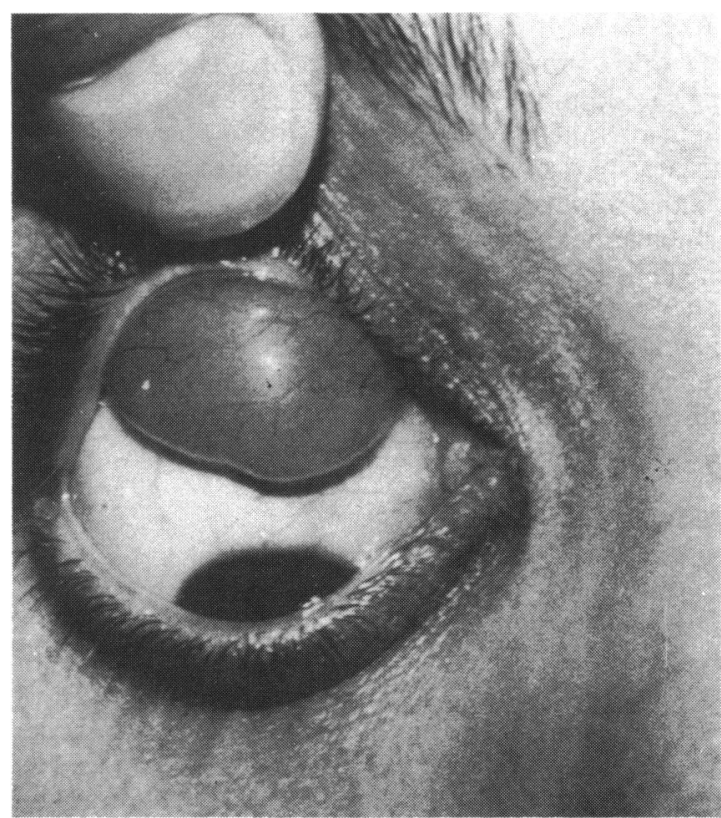

Fig. 2

Figs. 1 and 2 Mechanical ptosis of right eye and pseudostrabismus. Upper lid covers a smooth, globular mass. This mass, which can be depressed, had its base in the superior fornix and did not cause any inflammation. 
Fig. 3 Glandular tissue. The serous parts appear within the conjunctival tissue. A cystic dilatation is surrounded by multistratified epithelium.

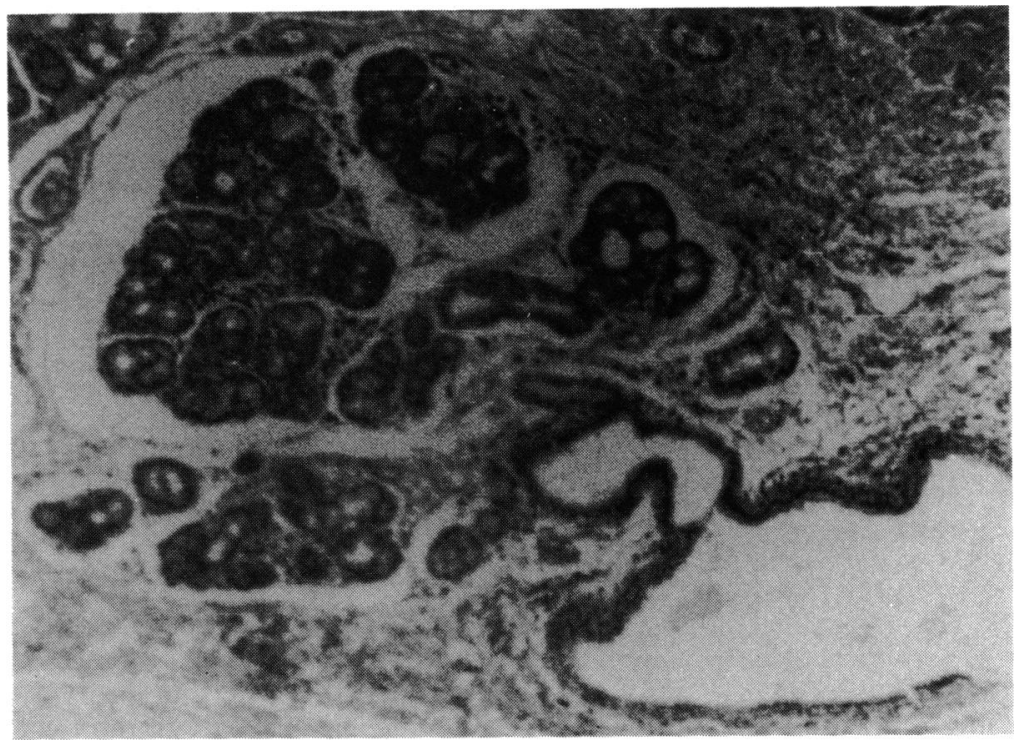

intralobular ducts, which become distended. This obstruction may be due to trauma or to chronic inflammation (trachoma, pemphigus, conjunctivitis), ${ }^{1}$ but the formation of these sort of cysts is much less frequent than might be expected, for the secretory epithelium of the gland usually atrophies.

In order to explain those cases in which a cyst due to retention appears without traumatic or inflammatory antecedents it has been suggested that there may be congenital anomalies of the excretory duct (agenesia, imperforation) or alterations in the composition of the secretory products, ${ }^{3}$ which, if excessively dense, may obstruct the excretory duct.

The seromucous nature of the secretion of the lacrimal glands should be noted. The predominance of a mucous secretion might favour the obstruction from which the cyst develops. During the histological preparation of the cyst under study serous acini were observed together with absolutely typical mucous acini.

\section{References}

1 Duke-Elder S. System of ophthalmology. London: Kimpton, 1974: 13: 642-3.

2 Reese A. Tumours of the eye. 3rd ed. New York: Harper and Row, 1976: 405.

3 Murube del Castillo J. Dacriología básica. Ponencia Oficial Soc Española de Oftalmologia. Las Palmas: Universidad de la Laguna, 1981: 329-30. 